\title{
Bidder’s Gain in Public M\&A Transactions: Does Size Matter?
}

\author{
Kenneth Högholm ${ }^{1}$ \\ ${ }^{1}$ Department of Finance and Statistics, HANKEN School of Economics, Vaasa, Finland \\ Correspondence: Kenneth Högholm, Department of Finance and Statistics, HANKEN School of Economics, P.O. \\ Box 287, 65101 Vaasa, Finland. E-mail: kenneth.hogholm@ hanken.fi
}

Received: February 1, 2016

Accepted: March 22, 2016

Online Published: April 25, 2016

doi:10.5539/ijef.v8n5p1

URL: http://dx.doi.org/10.5539/ijef.v8n5p1

\begin{abstract}
In this paper we investigate the short term abnormal return to the bidding firm's shareholders in takeovers made by a Finnish company during the time period from January 2000 to December 2013. Specifically, we study takeover transactions involving publicly traded target companies, and are particularly interested in the relationship between the abnormal return to bidder's shareholders and the size of the transaction. Specific features of the market for corporate acquisitions in Finland are that almost all transactions are friendly acquisitions and usually aim for $100 \%$ of the target company. We estimate the abnormal return around 51 individual takeover announcements and investigate determinants of the abnormal returns. Our results show that the takeover announcement on average yields a positive, but insignificant abnormal return to the bidding firm's shareholders. The announcement effect on the announcement day is $0.63 \%$, while the cumulative average abnormal return for an eleven day event window is $1.39 \%$. Both pre-event and post-event abnormal returns are statistically insignificant, although there is sign of a price run-up during the last week prior to the announcement. We document a significant negative relationship between the bidder's abnormal return on the announcement day and the size of the deal, but a positive relationship between the announcement effect and the relative size of the deal. We also document a weak negative relationship between the abnormal returns and the relative size of the target to the bidder. Among the other takeover characteristics we do not find any statistically significant relationship to the announcement effect.
\end{abstract}

Keywords: event study, market model, takeover, target size, value creation

\section{Introduction}

Corporate acquisition is a fast way for a company to grow compared to organic growth. Most bidding companies motivate this way to grow by the potential synergies that the acquisition creates, hence, one should expect the acquisition not only to create growth but also to create value for the acquiring firm's shareholders. However, empirical evidence from the takeover market report that bidding firm's shareholders at most earn small and/or insignificant returns, while target firm's shareholders earn large and significant returns in takeover transactions (Note 1). The low and sometimes even negative return to the bidder's shareholders is found especially in transactions involving a public target (see, e.g., Cai et al., 2011). One reason can be that the target may have a better negotiation power in a public tender offer compared to a private transaction. Another reason may be that the probability of the bid to succeed is lower in a public transaction.

The size of the target company has also been an important factor in explaining the gain to the bidder's shareholders. The empirical evidence regarding the relationship has been mixed. E.g., Moeller et al. $(2004,2005)$ support the notion that large transactions result in larger acquisition announcement returns, whereas, e.g., Al-Sharkas (2003) shows a negative correlation between the bidder abnormal return and relative size. Bradley and Sundaram (2004) show that when public targets are acquired with stock, the announcement effect is more negative the larger the target company.

The purpose of this study is to investigate the short term abnormal return to the bidding firm's shareholders in takeover transactions of a public target company by a Finnish bidder during the time period from January 2000 to December 2013. We are especially interested in how the announcement of an acquisition of a publicly traded company is perceived by the stock market, and to what extent the announcement effect correlates with the size of the transaction. To our knowledge there are very few studies focusing on the Finnish takeover market, and none studying the market during the last 15 years. Specific features of the market for corporate acquisitions involving 
a Finnish bidder are that almost all of the transactions are friendly acquisitions, and usually aim for $100 \%$ of the target company.

Due to the small number of publicly listed companies in Finland there are only a small number of transactions involving two publicly traded companies. We estimate the abnormal return around 51 individual takeover announcements and investigate determinants of the abnormal returns. Our results show that the takeover announcement on average yields a positive, but insignificant, abnormal return to the bidding firm's shareholders. The average abnormal return on the announcement day is $0.63 \%$, while the cumulative average abnormal return for an eleven day event window is $1.39 \%$. Both pre-event and post-event abnormal returns are statistically insignificant, although there is sign of a price run-up during the last week prior to the announcement. We document a significant negative relationship between the bidder's abnormal return on the announcement day and the size of the deal, but a positive relationship between the announcement effect and the relative size of the deal. We also document a weak negative relationship between the abnormal returns and the relative size of the target to the bidder. Among the other takeover characteristics we do not find any statistically significant relationship to the announcement effect.

The reminder of the paper is organized as follows. Section 2 summarizes the literature review on the motivations for takeovers and the determinants of the share price reaction to the takeover announcement. Section 3 describes the methodology and the data, while the empirical results are presented in Section 4. Section 5 concludes the study.

\section{Motives for Takeovers}

Three major takeover motives have been advanced in the literature implying gains for both the bidder and the Three major takeover motives have been advanced in the literature implying gains for both the bidder and the target, or negative return to the bidder. These are the synergy motive, the agency motive and the hubris hypothesis.

The synergy motive assumes that managers maximize shareholders' wealth and would engage in takeover activities only if it results in gains to the shareholders. Among the synergy motives, one set of motives is consistent with the assumption that additional value is created by takeovers (Note 2). The second set of motives cast doubt on whether any additional value is created by takeovers, or if the resulting gains to shareholders' is at the expense of other stakeholders (e.g., employees, customers, suppliers, tax payers) (Note 3).

According to the synergy motives, there should always be a positive gain in takeovers for all shareholders, stemming from efficiency improvements or from other stakeholders. Therefore, it follows that the measured gain to both target and bidder shareholders is expected to be positive. The division of the gain between target firm and acquiring firm shareholders may, though, not be equally distributed, but may be skewed in favor of the target due to a number of reasons (Note 4).

According to the agency theory (Jensen \& Meckling, 1976; Jensen, 1986) it has been suggested that some takeovers are primarily motivated by the self-interest of the acquirer management. Several reasons have been advanced to explain this divergence (Note 5). The basic idea in most of these explanations is that acquisitions result in an extraction of value from the acquirer shareholders by acquirer management.

The important aspect of the above argument is that the target firm has been identified by the acquirer management as one that is most suited to increase its own welfare. Therefore, target shareholders, realizing their value to the acquirer management, will attempt to obtain some of this value. To the extent that target shareholders have some bargaining power, they will succeed in doing so, and the value they obtain will increase with the amount that the acquirer management can appropriate. Therefore, the more severe the agency problem, the higher is the target's gain. Since greater appropriation by acquirer management also results in lower (or a negative) total gain, the observed gain to acquirer shareholder's should be small (compared to target shareholder's gain) or negative.

Roll (1986) hypothesizes that managers commit errors of over optimism in evaluating takeover opportunities due to excessive pride or hubris. Hence, the takeover premium is a random error, a mistake by the bidder. The hubris hypothesis assumes market efficiency. Stock prices reflect all information; redeployment of productive resources cannot bring gains, and management cannot be improved through reshuffling or combinations across firms. Roll (1986) claims that the hubris hypothesis thus serves as a benchmark for comparison and is the null hypothesis against which other hypotheses should be compared. Further, the hypothesis does not require conscious pursuit of self-interest by managers. Managers may have good intentions, but can make mistakes in judgment.

Since the takeover gain, according to the hubris hypothesis, is presumed to be close to zero, the payment to 
target shareholders represents a transfer between the target and the acquirer. It follows that the higher the target gain, the lower the bidder gain, and that the total gain is close to zero (e.g., Berkovitch \& Narayanan, 1993; Malmendier \& Tate, 2005).

\subsection{The Value Creation for Bidders and Its Determinants}

All of the above presented motives suggest that target shareholders experience a gain in takeovers. On the basis of the presented motives, however, the effect for the acquirer firm's shareholders is not clear. This is also evident in the presented empirical results across different stock markets, where some find positive, some negative and some insignificant bidder returns. The takeover literature has also shown that the characteristics of the deal will affect takeover returns, and, hence, the gain to the shareholders (Note 6).

Target size has been documented to play a significant role in determining bidder returns. However, the results have been conflicting with respect to the direction of the relationship. Kane (2000) and Moeller, Schlingemann and Stulz (2004) argue that large transactions result in value creation for the bidder shareholders. One reason may be that the larger the target company, the larger the potential synergy gain. Another reason may be that the combined institution may benefit from being too large to discipline adequately. On the other hand, e.g., Al-Sharkas (2003) shows a negative correlation between bidder abnormal return and relative size. Likewise, Bradley and Sundaram (2004) show that the announcement effect is more negative with increased target size. They argue that the managers of the bidding firm are likely to increase their compensation since acquisitions increase firm size. Hansen (1987) argued that a possible revaluation loss will be larger for the bidder the larger the target company. In this paper we are mainly interested in how the size of the deal and the relative size of the deal to the value of the bidder will affect the short term value creation to the bidding firms' shareholders. There are mixed results regarding this size effect, but we expect to find a negative relationship between the size of the target and the abnormal return to the bidder on the announcement day.

Conglomerate takeovers (diversification) may create operational and financial synergies, which may lower the financial risk, and, hence, the probability that the company goes bankrupt. This may also lower the cost of debt for the company (Agrawal, Jaffe, \& Mandelker, 1992). Diversification is also associated with a number of disadvantages stemming from the agency problem between managers and shareholders (e.g., Doukas, Holmen, \& Travos, 2002; Schafstein \& Stein, 2000), which may lead to lower takeover returns to bidders engaging in conglomerate takeovers. Mixed results have been documented for the value creation to the bidder's shareholders in conglomerate acquisitions. We expect, however, a more positive announcement response to a focused takeover compared to an announcement of a conglomerate takeover.

Martynova and Renneboog (2009) suggest that the method of payment may affect the short term market reaction to a takeover announcement. All cash bids are expected to generate a higher return to the shareholders than all-equity bids. The explanation is that asymmetric information implies that the bidder uses shares as a mean of payment when the share is overvalued, and uses cash when it is undervalued (Myers \& Majluf, 1984). Several studies have confirmed that the market reaction to announcements of equity offerings is significantly negative (e.g., Moeller, Schlingemann, \& Stulz, 2004; Moeller \& Schlingemann, 2005; Martynova \& Renneboog, 2011). Bradley and Sundaram (2004) show that when public targets are acquired with stock, the announcement effect is more negative the larger the target. In line with previous studies we expect a more positive announcement effect when the bid is an all-cash offering.

Cross border takeovers may open up an opportunity for the bidder to exploit market imperfections and to expand their business into new, international markets (e.g., Moeller \& Schlingemann, 2005). Since these effects are unavailable in domestic takeovers, one may expect a higher wealth effect in cross border deals. Martynova \& Renneboog (2008b) argue that takeover gains may be caused by improvements in governance of the bidder and the target firm. However, if there are large institutional differences in the bidder's and the target's countries, there may also be difficulties in the post-takeover process to utilize the perceived synergies. If the market anticipates such difficulties it may discount the expected gain. Conn, Cosh, Geust, and Hughes (2005) and Moeller and Schlingemann (2005) present evidence consistent with this hypothesis. Mixed results are documented with respect to cross border acquisitions. However, we expect to find a more positive announcement effect to a cross border deal.

Partial acquisitions, i.e., an acquisition of less than $100 \%$ of the equity, may lead to a higher takeover return to the bidder's shareholders. The bidder may use partial acquisitions as an instrument to transfer wealth from the target's minority shareholders by, e.g., using pyramidal control chains (La Porta et al., 1999; Bertrand \& Mullainathan, 2003). The possibility for value transfer is higher the lower the legal protection of the rights of the minority shareholders, i.e., when private benefits of control are high. We expect, therefore, a more positive 
announcement effect for partial acquisitions compared to full acquisitions (Note 7).

\section{Methodology and Data}

We study the short-term announcement effect to the bidder's shareholders in acquisitions of a publicly traded target company, and investigate several factors that may affect the stock market reaction to the takeover announcement. We measure the announcement effect as the sum of the daily average abnormal returns (Note 8) (CAAR) over different windows around the announcement day (Note 9), with a total event window of 41 days, 20 days prior to and 20 days after the event day. We also study alternative event windows before and after the announcement day to capture any effect of a price run-up before the event, or a possible value readjustment after the announcement day. The daily abnormal return (AR) is calculated as the difference between the actual return and the expected return:

$$
A R_{i t}=R_{i t}-E(R)_{i t},
$$

where $A R_{i t}$ is the abnormal return, $R_{i t}$ is the actual return, and $E(R)_{i t}$ the expected return. The expected return is calculated using alternative specifications; the market adjusted model, the market model, and the market model with adjusted beta (the estimated beta adjusted for mean reversion (Blume, 1979)). We use the value-weighted OMX Helsinki cap (Note 10) as a proxy for the market portfolio. The parameters in the market model are estimated using a window of 241 days, starting 300 days and ending 60 days prior to the event day.

To further study the market reaction to the takeover announcement, we regress the bidder's short term abnormal return on several explanatory factors with respect to the characteristics of the acquisition. The key characteristics we use are the size and the relative size of the transaction, the relative target size, the strategic scope of the transaction (focus or diversification), the mean of payments used in the deal, origin of the target company, and whether it is a full or a partial acquisition.

Our sample consists of all acquisitions of a publicly traded target company made by a Finnish stock market listed company during the time period from January 2000 to December 2013. The information about the acquisition is collected from the Thomson ONE Banker database, from stock exchange releases and from companies' homepages. There are a total of 51 acquisitions during the time period where both companies are publicly traded, and where the bidder acquires a majority stake in the target (more than $50 \%$ ownership). The sample consists of transactions that may be considered large enough to yield an observable stock market reaction to the announcement. We set the transaction value limit to 10 million USD.

Diversification was the dominant takeover strategy for the bidders in our sample. 32 of the 51 acquisitions were for a target company operating in a different industry than the bidder. 11 deals were all equity bids, while 32 deals were cross-border transactions. In 32 deals the bidder acquired the entire equity in the target company.

\section{Results}

Table 1, Panel A shows the descriptive statistics for the abnormal return on the announcement day, the cumulative abnormal return for an eleven day event window around the announcement day, and the size related variables used in the analysis. The table shows that the announcement of a takeover bid on average yields a positive abnormal return to the bidder's shareholders on the announcement day $(T=0)$. Using the market model (Note 11), the average abnormal return (AAR) is about 0.63 percent on the event day. For a longer event windows, 11 days centered at the announcement day, the cumulative average abnormal return (CAAR) increases to about 1.39 percent. We also document several extreme cases with both large positive and large negative abnormal returns. The mean transaction value is about 514 million USD (median 98 million), while the relative transaction value (transaction value to the size of the bidder) is about 0.23 (median 0.06). The relative value of the target to the value of the bidder is about 0.26 (median 0.13). Table 1, Panel B shows the correlation between the variables. There seems to be a negative relationship between the announcement effect and the size of the deal, measured as the transaction value in million USD. An opposite relationship is evident between the announcement effect and the relative deal value, measured as the value of the transaction to the value of the bidder prior to the announcement. The relationship is also positive between the announcement effect and the relative size of the target to the relative size of the bidder. 
Table 1. Descriptive statistics for 51 takeover transactions

\begin{tabular}{lccccc}
\hline Panel A: Descriptive statistics & \multicolumn{5}{c}{} \\
\hline & AAR $(\%)$ & CAAR $(\%)$ & TV & Relative TV & Relative TS \\
Mean & 0,63 & 1,39 & 514,36 & 0,23 & 0,26 \\
Median & 0,03 & 1,14 & 98,48 & 0,06 & 0,13 \\
Min & $-12,87$ & $-27,72$ & 10,34 & 0,00 & 0,00 \\
Max & 19,62 & 25,93 & 7953,59 & 1,76 & 1,27 \\
Std dev & 5,64 & 9,06 & 1345,51 & 0,40 & 0,34 \\
\hline Panel B: Correlation & & & & Relative DV & Relative TS \\
& AAR & CAAR & LOG(TV) & 0,062 \\
AAR & 1 & $0,481^{* *}$ & $-0,366^{* *}$ & 0,280 & 0,239 \\
CAR & & 1 & $-0,276^{*}$ & $0,313^{*}$ & $-0,062$ \\
LOG(TV) & & 1 & 0,151 & $0,536^{* *}$ \\
Relative TV & & & & 1 \\
Relative TS & & & & 1 \\
\hline
\end{tabular}

Panel A reports the descriptive statistics for 51 takeover transactions during the time period Jan 2000-Dec 2013. The average abnormal return (AAR) and the cumulative average abnormal return (CAAR) for an eleven day event window is calculated using the market model to estimate the expected return. The market return is calculated using the value-weighted total return index OMX Helsinki cap. The market model parameters are estimated over a period of 241 days starting 300 days before the announcement. $T V$ is the transaction value of the deal in million USD, Relative TV is the relative transaction value of the deal to the value of the bidder, Relative TS is the relative size of the target to the bidder prior to the takeover. Panel B of Table 1 presents the correlation between the variables. Statistical significance is denoted by $* / * * / * * *(10 \% / 5 \% / 1 \%)$.

Table 2 reports the cumulative abnormal return around the announcement for different event windows ranging from 20 days before to 20 days after the takeover announcement. Neither the announcement day nor any of the event windows exhibits a significant announcement return. We do, however, document some evidence of a price run-up in the pre-event period, mainly from days -7 to 0 , as is also evident from Figure 1.

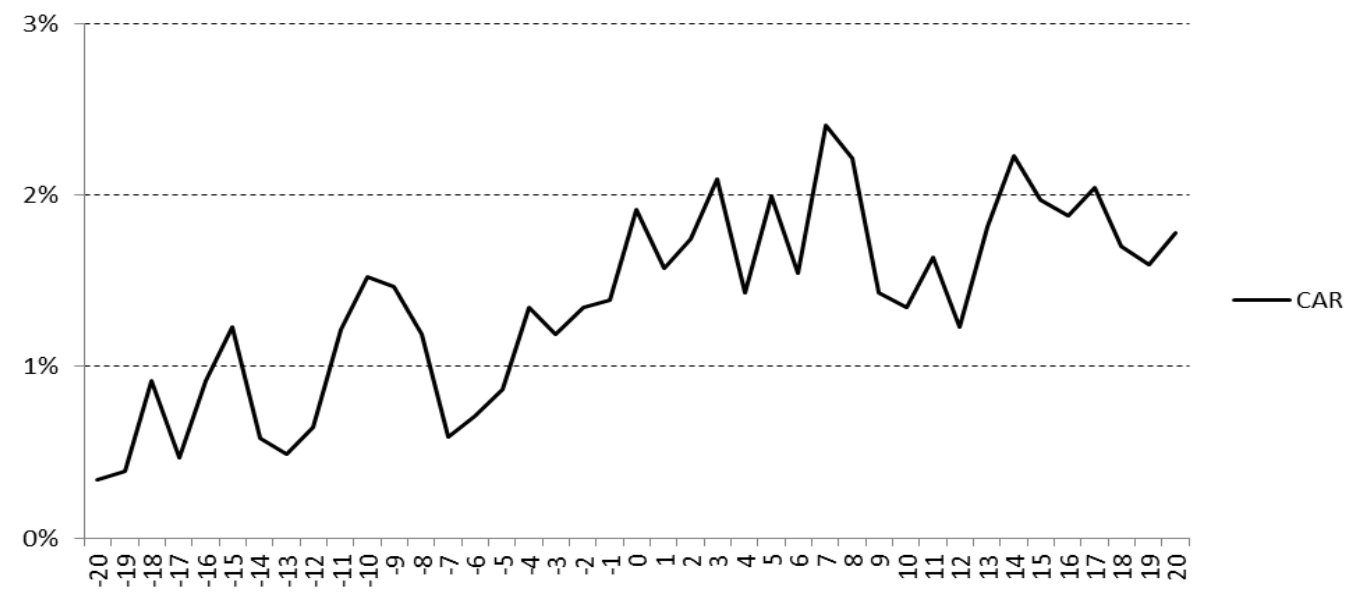

Figure 1. The cumulative average abnormal return (CAAR) for the bidding firms

The figure shows the cumulative average abnormal return (CAAR) for the bidding firm in 51 takeover transactions in Finland during the time period Jan 2000-Dec 2013 for an event window of 41 days. The abnormal return is calculated using the market model. The market return is based on the value-weighted total return index OMX Helsinki Cap. The market model parameters are estimated over a period of 241 days starting 300 days before the announcement. 
Table 2. Cumulative average abnormal returns (CAARs) for the bidding firms shareholders

\begin{tabular}{lcccc}
\hline Event window & $(\%)$ & $(\mathrm{p}$-value $)$ & Max $(\%)$ & Min $(\%)$ \\
\hline$[-20,+20]$ & 1.711 & 0.293 & 25.26 & -29.69 \\
{$[-10,+10]$} & 0.493 & 0.759 & 26.75 & -45.08 \\
{$[-5,+5]$} & 1.385 & 0.277 & 25.93 & -27.72 \\
{$[-3,+3]$} & 0.871 & 0.432 & 19.01 & -23.38 \\
{$[-1,+1]$} & 0.419 & 0.654 & 17.44 & -15.75 \\
{$[\mathrm{~T}=0]$} & 0.627 & 0.429 & 19.62 & -12.87 \\
{$[-20,-1]$} & & & & -17.23 \\
{$[-10,-1]$} & 1.202 & 0.397 & 29.38 & -15.03 \\
{$[-5,-1]$} & 0.237 & 0.829 & 27.12 & -13.13 \\
{$[-3,-1]$} & 0.497 & 0.560 & 18.70 & -12.92 \\
{$[+1,+20]$} & -0.186 & 0.763 & 9.13 & -26.94 \\
{$[+1,+10]$} & & & & -20.57 \\
{$[+1,+5]$} & -0.118 & 0.920 & 16.51 & -20.94 \\
{$[+1,+3]$} & -0.371 & 0.727 & 9.75 & -22.35 \\
\hline
\end{tabular}

The table reports cumulative average abnormal returns (CAAR) for the bidding firms shareholders in 51 takeover transactions during the time period Jan 2000-Dec 2013 over different event windows. The expected return is calculated using the market model. The market return is calculated using the value-weighted total return index OMX Helsinki cap. The market model parameters are estimated over a period of 241 days starting 300 days before the announcement. Statistical significance is denoted by $* / * * * * *(10 \% / 5 \% / 1 \%)$.

Overall, we show that the short term bidder return is on average positive, although not statistically significant. The returns accumulate mostly during an eleven day event window centered on the event day, with a large fraction of the market reaction to the bid occurring at the announcement day. Hence, the announcement of an acquisition of a publicly traded target company is on average at least not a value destroying event for the bidder's shareholders, indicating that the main motive for the transaction is to create value to the shareholders (Note 12).

Table 3. Number of positive and negative stock market reactions

\begin{tabular}{lccccc}
\hline & \multicolumn{2}{c}{ Event day $[\mathrm{T}=0]$} & & \multicolumn{2}{c}{ CAR $[-5,+5]$} \\
\cline { 2 - 3 } \cline { 5 - 6 } & Number & $\%$ & 51.0 & Number & $\%$ \\
\hline Positive & 26 & 49.9 & 31 & 60.8 \\
Negative & 25 & 100 & 20 & 39.2 \\
Total & 51 & 51 & & 100 \\
\hline
\end{tabular}

The table reports the number of events with positive and negative abnormal returns in 51 takeover transactions in Finland during the time period Jan 2000-Dec 2013. The abnormal returns are calculated using the market model, where the market return is based on the value-weighted total return index OMX Helsinki cap. The market model parameters are estimated over a period of 241 days starting 300 days before the announcement.

However, the results are ambiguous as is also evident from Table 3, in which we report the number of announcements that yields a positive and a negative market reaction, respectively. Out of the 51 announcements, 26 had a positive abnormal return on the announcement day. Hence, we cannot rule out that some of the acquisitions are driven by hubris or agency motives, since 25 announcements yielded a negative abnormal announcement day return.

Target size is one of the deal characteristics that may explain the short term value creation to the bidder in takeover transactions. However, there are several other deal characteristics that may affect the market response to the announcement. In Table 4 we report the market reaction to the takeover announcement by some deal characteristics (Note 13). 
Table 4. Average abnormal (AAR) and cumulative average abnormal return (CAAR) for the bidding firm by different characteristics of the acquisition

\begin{tabular}{|c|c|c|c|c|c|c|c|}
\hline \multicolumn{4}{|c|}{$\mathrm{AAR}[\mathrm{t}=0]$} & \multicolumn{4}{|c|}{ CAAR [-5:5] } \\
\hline & $(\%)$ & (p-value) & Nobs & & $(\%)$ & (p-value) & Nobs \\
\hline Whole sample & $0.63 \%$ & 0.43 & 51 & Whole sample & $1.39 \%$ & 0.28 & 51 \\
\hline Diversification & $0.70 \%$ & & 32 & Diversification & $1.86 \%$ & & 32 \\
\hline Non-diversification & $0.50 \%$ & & 19 & Non-diversification & $0.59 \%$ & & 19 \\
\hline Difference & $0.20 \%$ & 0.90 & & Difference & $1.27 \%$ & 0.63 & \\
\hline Stock only & $3.65 \%$ & & 11 & Stock only & $4.51 \%$ & & 11 \\
\hline Other payments & $-0.20 \%$ & & 40 & Other payments & $0.53 \%$ & & 40 \\
\hline Difference & $3.85 \%{ }^{* *}$ & 0.04 & & Difference & $3.98 \%$ & 0.20 & \\
\hline Cross border & $0.32 \%$ & & 32 & Cross border & $0.33 \%$ & & 32 \\
\hline Domestic & $1.15 \%$ & & 19 & Domestic & $3.17 \%$ & & 19 \\
\hline Difference & $-0.83 \%$ & 0.62 & & Difference & $-2.84 \%$ & 0.28 & \\
\hline $100 \%$ acquired & $0.57 \%$ & & 32 & $100 \%$ acquired & $1.92 \%$ & & 32 \\
\hline Less acquired & $0.72 \%$ & & 19 & Less acquired & $0.49 \%$ & & 19 \\
\hline Difference & $-0.15 \%$ & 0.93 & & Difference & $1.43 \%$ & 0.59 & \\
\hline
\end{tabular}

The table reports the average abnormal return (AAR) and the cumulative average abnormal returns (CAAR) over an eleven day event window for the bidding firm in 51 takeover transactions in Finland during the time period Jan 2000-Dec 2013, and for different characteristics of the acquisition. The abnormal returns are calculated using the market model, where the market return is based on the value-weighted total return index OMX Helsinki cap. The acquisition characteristics are the bid being for a company within the same industry or for an unrelated company (based upon the SIC-code), the terms of payment (stock or other), the origin of the target (cross border or domestic), and the bid being non-partial or not (100\% acquired or less). Statistical significance are denoted by $* / * * * * * *(10 \% / 5 \% / 1 \%)$.

Most of the acquisitions made by Finnish bidders are for a target company operating in an unrelated industry, i.e., a diversification takeover. However, the market response to the announcement of an unrelated target is similar to the announcement of a focused deal. The difference is not significant on conventional significance levels.

We document a statistically significant difference in the announcement effect of stock only versus other types of bids. The announcement effect is significantly higher for stock only bids at the announcement day (3.65 versus -0.20 percent). The cumulative average abnormal return for the eleven day event window is also higher for stock only bids, although not statistically significant.

Most of the bids are for a foreign target company. Overall, the bidder experience a small positive announcement effect for both cross-border and domestic bids, but the announcement effect is lower for bidders engaging in cross-border transactions ( 0.32 versus 1.15 percent). The difference is even larger in the eleven day event window, but the difference is statistically insignificant.

Finally, in Table 4, we also report the announcement effect for non-partial versus partial bids. The market response to the announcement is on average slightly positive to both acquisition types, and no significant difference in the response can be detected.

The univariate tests show that there may be a different market response to an announcement of an acquisition based upon the size of the parties involved and the characteristics of the bid. In Table 5 we report the results from an OLS-regression of the market reaction using the bid characteristics as explanatory variables.

Table 5. Determinants of the cumulative abnormal return (CAR)

\begin{tabular}{lcccccccc}
\hline & \multicolumn{2}{c}{ AR $[\mathrm{t}=0]$} & \multicolumn{3}{c}{} & \multicolumn{3}{c}{ CAR[-5;+5] } \\
\hline & \multicolumn{2}{c}{$(1)$} & \multicolumn{2}{c}{$(2)$} & \multicolumn{3}{c}{ (3) } & \multicolumn{2}{c}{$(4)$} \\
Dependent variable & coeff. & p-value & coeff. & p-value & coeff. & p-value & coeff. & p-value \\
\hline Intercept & $0.077^{* * *}$ & 0.00 & $0.069^{* *}$ & 0.03 & 0.085 & 0.10 & 0.081 & 0.27 \\
LOG(Transaction value) & $-0.037^{* * *}$ & 0.00 & $-0.034^{* * *}$ & 0.00 & $-0.044^{*}$ & 0.09 & -0.043 & 0.13 \\
Relative transaction value & $0.065^{* *}$ & 0.02 & $0.068^{* *}$ & 0.01 & $0.079^{* *}$ & 0.05 & 0.071 & 0.13 \\
Relative target size & -0.037 & 0.14 & $-0.046^{*}$ & 0.07 & 0.009 & 0.83 & 0.010 & 0.84 \\
Diversification & & & 0.002 & 0.90 & & & 0.012 & 0.69 \\
Stock only & & & 0.038 & 0.23 & & & -0.001 & 0.97 \\
Cross border & & 0.016 & 0.43 & & & -0.017 & 0.59 \\
\hline
\end{tabular}




\begin{tabular}{|c|c|c|c|c|c|c|c|c|}
\hline Acquiring $100 \%$ of shares & & & -0.022 & 0.18 & & & 0.012 & 0.65 \\
\hline F-stat. & $5.68^{* * *}$ & 0.00 & $3.13^{* * *}$ & 0.01 & $4.07^{* *}$ & 0.01 & 1.71 & 0.13 \\
\hline Adjusted $\mathrm{R}^{2}$ & 0.266 & & 0.230 & & 0.155 & & 0.091 & \\
\hline Number of acquisitions & 51 & & 51 & & 51 & & 51 & \\
\hline
\end{tabular}

The table reports the results of the OLS regression of the cumulative abnormal return (CAR) for the bidders in 51 takeover transactions in Finland during the time period Jan 2000-Dec 2013. Transaction value is the value of the bid in million USD, relative transaction value is the relative value of the deal to the value of the bidder, relative target size is the relative size of the target to the bidder prior to the takeover, diversification is a dummy variable taking the value 1 when the target operates in a different industry than the bidder according to their industry classification (SIC-code), stock only is a dummy variable taking the value 1 when the acquisition is paid for in stock, cross border is a dummy variable taking the value 1 when the target company is of foreign origin and acquiring $100 \%$ of shares is a dummy variable taking the value of 1 if the bidder acquires all shares. All regressions contain White's heteroskedastic-consistent standard errors. Statistical significance are denoted by $* / * * / * * *(10 \% / 5 \% / 1 \%)$.

In the analysis of the market response on the announcement day we see that most of the results from the regression analysis are consistent with the findings in the univariate analysis. Specifically, when looking at the size related variables, we see that there is a significant negative relationship between the bidder's abnormal return and the size of the deal, indicating that the market expect that the bidding firm may face large post-acquisition integration costs which will reduce the takeover synergy (Martynova \& Renneboog, 2011), or that the acquisition is mainly driven by agency motives or by over optimism. However, looking at the relative size of deal to the value of the bidder we document a statistically significant positive relationship. Hence, the results suggest that the larger the deal is to the value of the bidder, the more careful the bidder is in evaluating the target and the more likely it is that the transaction is driven by value creation, and that the bidder's shareholders also capture some part of this gain. The relationship between the announcement effect and the relative size of the target is negative and statistically insignificant. The results are similar looking at the eleven day event window, although the estimates are less significant.

The results regarding the size variables are robust when including the other deal characteristics variables in the models. There are indications of the market perceiving stock only announcements to be good news, rewarding the bid with a higher positive (not significant) abnormal return than a corresponding announcement involving mixed or cash payments. There are also some indications of a lower abnormal return when the bidder acquires $100 \%$ of the target, but the effect is not statistically significant. There is no difference in the announcement effect whether the target operates in the same industry or not, or in the origin of the target company.

\section{Conclusions}

In this study, we analyze the short term market reactions to takeover announcements in a sample of 51 acquisitions of a publicly traded company made by a stock market listed Finnish company during the time period from January 2000 to December 2013. The acquisitions made by Finnish companies during the studied period were characterized by a diversification strategy involving a foreign target company. The acquisition was typically friendly, and aimed for the entire capital of the target company. We document that the event, on average, has at best a small positive short term value creating effect for the bidder's shareholders. The average abnormal return is 0.63 percent on the announcement day, but the return is not statistically significant. This result confirms the result from previous studies involving publicly traded targets that the returns to the bidding firms' shareholders are on average close to zero. Neither the pre-event nor the post-event abnormal returns are statistically significant, although there is sign of a price run-up prior to the announcement day.

We also investigate the relationship between the market reaction to the announcement and deal characteristics. We document a significant, negative relationship between the size of the transaction and the abnormal return on the announcement day. However, looking at the size of the transaction in relation to the size of the bidder we find a reversed relationship, i.e., the larger the relative size of the deal, the more positive the announcement effect. This indicates that the size of the two companies involved in the transaction is an important variable in explaining the observed market response to the announcement. The result indicates that the larger the value of the transaction (the value of the target net the bidder toehold), the better is the target's negotiation power and/or the harder is the post-acquisition integration. Alternatively, larger acquisitions are more likely driven by agency motives or over optimism. The results also indicate that the larger the transaction value to the value of the bidder, the more likely it is that the acquisition is driven by value creation.

The also document signs of a more favorable market reaction to an acquisition where the bidder uses stock as the mean of payment. If the bidder aims for 100 percent of the target we find indication of an announcement day 
return being smaller than in a partial acquisition. We do not find any significant relationship between the announcement effect and the relatedness of the industries (focused or diversification), or origin of the target company.

\section{References}

Agrawal, A., \& Jaffe, J. (2000). The post-merger performance puzzle. Advances in Mergers and Acquisitions, 1 , 7-41. http://dx.doi.org/10.1016/s1479-361x(00)01002-4

Agrawal, A., Jaffe, J., \& Mandelker, G. (1992). The post-merger performance of acquiring firms: A re-examination of an anomaly. Journal of Finance, 47, 1605-1621. http://dx.doi.org/10.1111/j.1540-6261.1992.tb04674.x

Al-Sharkas, A. (2003). Shareholder wealth effect in bank mergers: New evidence during the period 1980-2000. In 2003 Proceedings from AFFI, Paris.

Amihud, Y., \& Lev, B. (1981). Risk reduction as a managerial motive for conglomerate mergers. Bell Journal of Economics, 12, 605-617. http://dx.doi.org/10.2307/3003575

Auerbach, A., \& Reishaus, D. (1987). The effects of taxation on the merger decision. National Bureau of Economic Research, Working paper.

Berkovitch, E., \& Narayanan, M. (1993). Motives for takeovers: an empirical investigation. Journal of Financial and Quantitative Analysis, 28, 347-362. http://dx.doi.org/10.2307/2331418

Bertrand, M., \& Mullainathan, S. (2003). Pyramids. Journal of the European Economic Association, 1, 478-483. http://dx.doi.org/10.1162/154247603322391116

Blume, M. (1979). Betas and their regression tendencies: Some further evidence. Journal of Finance, 34, 265-267. http://dx.doi.org/10.1111/j.1540-6261.1979.tb02088.x

Bradley, M., \& Sundaram, A. (2004). Do acquisitions drive performance or does performance drive acquisitions? SSRN Working paper.

Bradley, M., Desai, A., \& Kim, H. E. (1988). Synergistic gains from corporate acquisitions and their division between the stockholders of target and acquiring firms. Journal of Financial Economics, 21, 3-40. http://dx.doi.org/10.1016/0304-405X(88)90030-X

Bruner, R. (2004). Does M\&A pay? Applied Mergers and Acquisitions, 1, 11-15.

Cai, J., Song, M., \& Walking, R. (2011). Anticipation, acquisitions, and biddr returns: Industry shocks and the transfer of information across rivals. Review of Financial Studies, 24, 2242-85. http://dx.doi.org/10.1093/rfs/hhr035

Chappell, H., \& Cheng, D. (1984). Firms' acquisition decisions and Tobin's Q ratio. Journal of Economics and Business, 2, 29-42. http://dx.doi.org/10.1016/0148-6195(84)90010-9

Conn, R., Cosh, A., Guest, P., \& Hughes, A. (2005). The impact on UK acquiriers of domestic, cross-border, public and private acquisitions. Journal of Business Finance and Accounting, 32, 815-870. http://dx.doi.org/10.1111/j.0306-686X.2005.00615.x

Dennis, D., \& McConnell, J. (1986). Corporate mergers and security returns. Journal of Financial Economics, 16, 143-187. http://dx.doi.org/10.1016/0304-405X(86)90059-0

Doukas, J., Holmen, M., \& Travlos, N. (2002). Diversification, ownership, and control of Swedish corporations. European Financial Management, 8, 281-314. http://dx.doi.org/10.1111/1468-036X.00190

Eckbo, E. (1992). Mergers and the value of antitrust dererrence. Journal of Finance, 47, 1005-1029. http://dx.doi.org/10.1111/j.1540-6261.1992.tb04003.x

Fishman, M. (1988). A theory of preemptive takeover bidding. Rand Journal of Economics, 19, 88-101. http://dx.doi.org/10.2307/2555399

Goergen, M., \& Renneboog, L. (2004). Shareholders wealth effects of European domestic and cross-border bids. European Financial Management, 10, 9-45. http://dx.doi.org/10.1111/j.1468-036X.2004.00239.x

Goergen, M., Martynova, M., \& Renneboog, L. (2005). Corporate governance convergence: Evidence from takeover regulation reforms. Oxford Review of Economic Policy, 21, 243-268. http://dx.doi.org/10.1093/oxrep/gri015

Grossman, S., \& Hart, O. (1980). Takeover bids, the free rider problem, and the theory of the corporation. Bell 
Journal of Economics, 11, 42-64. http://dx.doi.org/10.2307/3003400

Hamza, T. (2011). Determinants of short-term value creation for the bidder: Evidence from France. Journal of Management \& Governance, 15, 157-186. http://dx.doi.org/10.1007/s10997-009-9094-9

Hansen, R. (1987). A theory for the choice of exchange medium in mergers and acquisitions. Journal of Business 60, 75-95. http://dx.doi.org/10.1086/296386

Harris, E. (1990). Anti-takeover measures, golden parachutes, and target firm shareholder welfare. Rand Journal of Economics, 21, 614-625. http://dx.doi.org/10.2307/2555472

Högfeldt, P., \& Högholm, K. (2000). A law and finance theory of strategic blocking and preemptive bidding in takeovers. Journal of Corporate Finance, 6, 403-425. http://dx.doi.org/10.1016/S0929-1199(00)00015-8

Jarrell, G., Brickley, J., \& Netter, J. (1988). The market for corporate control: The empirical evidence since 1980. Journal of Economic Perspectives, 2, 49-68. http://dx.doi.org/10.1257/jep.2.1.49

Jensen, M., \& Meckling, W. (1976). Theory of the firm: Managerial behavior, agency costs and ownership structure. Journal of Financial Economics, 3, 305-360. http://dx.doi.org/10.1016/0304-405X(76)90026-X

Jensen, M., \& Ruback, R. (1983). The market for corporate control: The scientific evidence. Journal of Financial Economics, 11, 5-50. http://dx.doi.org/10.1016/0304-405X(83)90004-1

Jensen, M. (1986). Agency cost of free cash flow, corporate finance and takeovers. American Economic Review, 76, 323-329.

Kane, E. (2000). Incentives for banking megamergers: What motives might regulators infer from event-study evidence? Journal of Money, Credit and Banking, 32, 671-701. http://dx.doi.org/10.2307/2601202

La Porta, R., Lopez-de-Silanes, F., Shleifer, A., \& Vishny, R. (1999). Ownership around the world. Journal of Finance, 54, 471-517. http://dx.doi.org/10.1111/0022-1082.00115

La Porta, R., Lopez-de-Silanes, F., Shleifer, A., \& Vishny, R. (2002). Investor protection and corporate valuation. Journal of Finance, 57, 1147-1170. http://dx.doi.org/10.1111/1540-6261.00457

Lakonishok, J., Shleifer, A., \& Vishny, R. (1994). Contrarian investment, extrapolation, and risk. Journal of Finance, 49, 1541-1578. http://dx.doi.org/10.1111/j.1540-6261.1994.tb04772.x

Malmendier, U., \& Tate, G. (2005). Does overconfidence affect corporate investment? CEO overconfidence measures revisited. European Financial Management, 11, 649-659. http://dx.doi.org/10.1111/j.1354-7798.2005.00302.x

Martynova, M., \& Renneboog, L. (2008a). A century of corporate takeovers: What have we learned and where do we stand? Journal of Banking and Finance, 32, 2148-2177. http://dx.doi.org/10.1016/j.jbankfin.2007.12.038

Martynova, M., \& Renneboog, L. (2008b). Spillover of corporate governance standards in cross-border mergers $\begin{array}{lllll}\text { and acquisitions. Journal of Corporate } & \text { Finance, } 23 .\end{array}$ http://dx.doi.org/10.1016/j.jcorpfin.2008.03.004

Martynova, M., \& Renneboog, L. (2009). What determines the financing decision in corporate takeovers: Cost of capital, agency problems or the means of payment? Journal of Corporate Finance, 15, 290-315. http://dx.doi.org/10.1016/j.jcorpfin.2008.12.004

Martynova, M., \& Renneboog, L. (2011). The performance of the European market for corporate control: Evidence from the fifth takeover wave. European Financial Management, 17, 208-259. http://dx.doi.org/10.1111/j.1468-036X.2009.00497.x

Moeller, S., \& Schlingemann, F. (2005). Global diversification and bidder gains: A comparison between cross-border and domestic acquisitions. Journal of Banking and Finance, 29, 533-564. http://dx.doi.org/10.1016/S0378-4266(04)00047-0

Moeller, S., Schlingemann, F., \& Stulz, R. (2004). Firm size and the gain from acquisitions. Journal of Financial Economics, 73, 201-228. http://dx.doi.org/10.1016/j.jfineco.2003.07.002

Moeller, S., Schlingemann, F., \& Stulz, R. (2005). Wealth destruction on a massive scale? A study of acquiring-firm returns in the recent merger wave. Journal of Finance, 60, 757-782. http://dx.doi.org/10.1111/j.1540-6261.2005.00745.x

Myers, S., \& Majluf, N. (1984). Corporate financing and investment decisions when firms have information that investors do not have. Journal of Financial Economics, 13, 187-221. 
http://dx.doi.org/10.1016/0304-405X(84)90023-0

Prescott, E., \& Visscher, M. (1980). Organization capital. Journal of Political Economy, 88, 446-461. http://dx.doi.org/10.1086/260879

Rau, R., \& Vermaelen, T. (1998). Glamour, value and post-acquisition performance of acquiring firms. Journal of Financial Economics, 49, 223-253. http://dx.doi.org/10.1016/S0304-405X(98)00023-3

Roll, R. (1986). The hubris hypothesis of corporate takeovers. The Journal of Business, 59, 197-216. http://dx.doi.org/10.1086/296325

Shleifer, A., \& Summers, L. (1988). Breach of trust in hostile takeovers. In Corporate takeovers: Causes and consequences, University of Chicago Press, Chicago.

Shleifer, A., \& Vichny, R. (1989). Managerial entrenchment: The case of managerial-specific investments. Journal of Financial Economics, 25, 123-139. http://dx.doi.org/10.1016/0304-405X(89)90099-8

Stulz, R., Walking, R., \& Song, M. (1990). The distribution of target ownership and the division of gains in $\begin{array}{lllll}\text { successful takeovers. Journal of } & \text { Finance, } & 45,833 .\end{array}$ http://dx.doi.org/10.1111/j.1540-6261.1990.tb05107.x

Sudarsanam, S., \& Mahate, A. (2003). Glamour acquirers, method of payment and post-acquisition performance: The UK evidence. Journal of Business Finance and Accounting, 30, 299-341. http://dx.doi.org/10.1111/1468-5957.00494

Summer, C. (1980). Strategic behavior in business and government. Little, Brown and Company, Boston.

\section{Notes}

Note 1. For an overview of the wealth effects of takeover transactions, see, e.g., Jensen \& Ruback, 1983; Jarrell, Brickley, \& Netter, 1988; Agrawal \& Jaffe, 2000; Bruner, 2004; and Martynova \& Renneboog, 2008a.

Note 2. E.g., the inefficient management motive (e.g., Bradley, Desai, \& Kim, 1988), the financial synergy motive (e.g., Prescott \& Visscher, 1980), strategic alignment to changing environments (e.g., Summer, 1980), the undervaluation theory (e.g., Chappell \& Cheng, 1984), the information hypothesis (e.g., Bradley, Desai, \& Kim, 1988).

Note 3. E.g., the market power hypothesis (e.g., Eckbo, 1992), the tax motive (e.g., Auerbach \& Reishaus, 1987), increased financial risk (e.g., Dennis \& McConnel, 1986), employees deprived from their benefits (e.g., Shleifer $\&$ Summers, 1988).

Note 4. E.g., free riding (Grossman \& Hart, 1980), bidder competition (e.g., Fishman, 1988), takeover defense measures (e.g., Harris, 1990), bargaining power (e.g., Högfeldt \& Högholm, 2000).

Note 5. E.g., diversification of management's personal portfolio (Amihud \& Lev, 1981), increasing the size of the firm (Jensen, 1986), and acquiring assets that increase the firm's dependence on the management (Shleifer \& Vishny, 1989).

Note 6. For an overview of the empirical evidence, see, e.g., Jensen \& Ruback, 1983; Agrawal and Jaffe, 2000; Bruner, 2004; Martynova \& Renneboog, 2008a.

Note 7. Other proposed takeover characteristics that may affect the short-term value creation to the bidder are, e.g., value vs. growth (Lakonishok, Shleifer, \& Vishny, 1994; Sudarsanam \& Mahate, 2003); friendly vs. hostile (Goergen \& Renneboog, 2004); tender offers vs. mergers (Rau \& Vermaelen, 1998); target ownership structure (Högfeldt \& Högholm, 2000; Martynova \& Renneboog, 2008a); bidder toehold (Stulz, Walking, \& Song, 1990), Hamza, 2011); investor protection (La Porta, Lopez-de-Silanes, Shleifer, \& Vishny, 2002; Goergen, Martynova, \& Renneboog, 2005; Martynova \& Renneboog, 2008b); partial acquisitions (La Porta, Lopez-de-Silanes, Shleifer, \& Vishny, 2002); takeover waves (Martynova \& Renneboog, 2011).

Note 8 . The returns are continuously compounded returns.

Note 9. The event day (announcement day) is defined as the day when the information of the takeover was announced for the first time (or the day after if the announcement occurred after the closing of the trading day or on a non-trading day).

Note 10. We use the restricted version of the market index (OMX Helsinki cap) which restricts the weight of any individual company to a maximum of ten percent in the index. This is due to the large weight of some companies in the unrestricted market index, e.g., the weight of Nokia was about 60 percent in the index in year 2000. 
Note 11. We choose to only report the results using the market model to calculate the abnormal return. Our results are robust to the choice of estimation model of the benchmark returns. The results using the market adjusted model or the market model with adjusted beta are available upon request.

Note 12. In addition, the average abnormal return for the sample of publicly traded target firms was 38.4 percent on the announcement day.

Note 13. In the remainder of the paper we report the results on the announcement day and for an event window of eleven days centered at the announcement day using the market model returns as the benchmark returns. Using a longer event window and/or the two alternative estimation models does not materially change the results.

\section{Copyrights}

Copyright for this article is retained by the author(s), with first publication rights granted to the journal.

This is an open-access article distributed under the terms and conditions of the Creative Commons Attribution license (http://creativecommons.org/licenses/by/3.0/). 